\title{
Task 8.8 - Low Cost Ceramic Materials
}

\author{
Topical Report \\ June 30, 1997
}

RECEIVED

JAN 264998

OSTI

Work Performed Under Contract No.: DE-AC21-93MC30246

For

U.S. Department of Energy

Office of Fossil Energy

Federal Energy Technology Center

Morgantown Site

P.O. Box 880

Morgantown, West Virginia 26507-0880

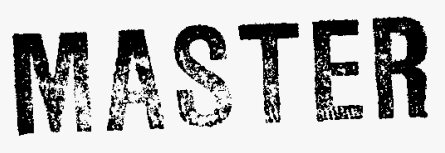

By

Solar Turbines, Inc.

2200 Pacific Highway

San Diego, California 92186-5376

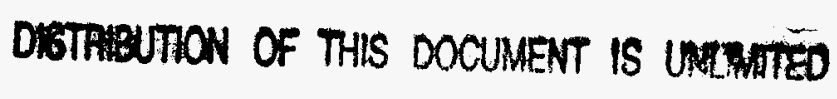




\section{Disclaimer}

This report was prepared as an account of work sponsored by an agency of the United States Government. Neither the United States Government nor any agency thereof, nor any of their employees, makes any warranty, express or implied, or assumes any legal liability or responsibility for the accuracy, completeness, or usefulness of any information, apparatus, product, or process disclosed, or represents that its use would not infringe privately owned rights. Reference herein to any specific commercial product, process, or service by trade name, trademark, manufacturer, or otherwise does not necessarily constitute or imply its endorsement, recommendation, or favoring by the United States Government or any agency thereof. The views and opinions of authors expressed herein do not necessarily state or reflect those of the United States Government or any agency thereof. 


\section{CONTENTS}

\section{Paragraph}

Page

1.0

INTRODUCTION

2.0

MODIFICATION OF PROGRAM

3.0

MATERIAL SELECTION AND PROPERTIES

3.1 LoTec BZP

3

3.2 SAIC CMC-8

5

3.3 International Thermoproducts Altra KVS 16 With Ceramic Fabric Reinforcement

4.1 LoTec BZP Liner Subscale Rig Test

4.2 SAIC CMC-8 Liner Subscale Rig Test

4.3 ITP CF3000 Liner Subscale Rig Test

5.0 


\section{FIGURES}

Figure

Page

TABLES

\section{Table}

Page

1

Candidate Ceramic Materials for the Combustor Application

2

BZP Material Properties

3

Stresses for BZP Liner With cte $=0.5 \times 10^{-6} /{ }^{\circ} \mathrm{F}$

4

4

Stresses for BZP Liner With cte $=1.7 \times 10^{-6} /{ }^{\circ} \mathrm{F}$

5

5

Material Properties of SAIC S2 Glass Reinforced CMC-8

4

Physical Properties of CF 3000 Vacuum Formed Ceramic Fiber 


\subsection{INTRODUCTION}

This subtask was originally titled "Reheat Combustor Materials" and was proposed in anticipation of the addition of a reheat combustor to the ICR gas turbine cycle. When the emphasis of ATS became the optimized recuperated cycle, the goal of the subtask was changed to the evaluation of low cost materials for gas turbine combustor liners. It now supplements similar work being conducted by Solar under DOE Contract No.DE-AC02-92-CE40960, titled "Ceramic Stationary Gas Turbine (CSGT) Development." The use of a ceramic combustor liner in gas turbines contributes to emissions reductions by freeing cooling air for use as primary combustion air and by allowing higher wall temperatures, which contribute to more complete combustion of hydrocarbons.

Information from a literature's suney, manufacturer's data, and Solar experience was used to select three materials for testing. In addition to material properties requirements for selection, subscale combustor liner cost was required to be at least half of the high modulus continuous fiber reinforced composite part cost. The three materials initially selected for evaluation are listed in Table 1. Four hour subscale rig tests were planned for eight inch diameter liners made from each material. Upon successful completion of each four hour test, a fifty hour test was planned.

Table 1. Candidate Ceramic Materials for the Combustor Application

\begin{tabular}{|c|c|c|}
\hline Material Name & Type & Supplier \\
\hline \hline B-30 & Barium Zirconia Phosphate & LoTEC \\
\hline Altra KVS 16 & $\begin{array}{c}\text { High Alumina Fiber } \\
\text { Reinforced Composite }\end{array}$ & International Thermoproducts \\
\hline $\begin{array}{c}\text { System 2.2 High } \\
\text { Temperature Composite }\end{array}$ & $\begin{array}{c}\text { Glass-Ceramic Fiber } \\
\text { Reinforced Composite }\end{array}$ & AEA Technologies \\
\hline
\end{tabular}

In addition to rig testing, cyclic thermal/erosion testing at ITP was planned for comparative analysis of different fiber blends in the Altra KVS material. The test apparatus consists of a gas burner that automatically cycles on and off for 695 cycles per day. Test specimens are soaked to about $2350^{\circ} \mathrm{F}$ $\left(1288^{\circ} \mathrm{C}\right)$ at the end of the test cycle. 


\subsection{MODIFICATION OF PROGRAM}

AEA Technologies, formerly a U.K. govemment organization, was privatized after being selected for participation in this program. After reorganizing, they were unable to use their subcontractor for HIPing the System 2.2 glass ceramic composite in the eight inch subscale combustor size. Therefore, AEA Technologies was dropped from the program, and a relatively low cost Nextel 440 fiber reinforced glass-ceramic composite from Scientific Applications International Corporation (SAIC) was chosen as a replacement (CMC-SAIC-8). 


\subsection{MATERIAL SELECTION AND PROPERTIES}

The CSGT program tested 8 inch subscale combustor liners of silicon carbide composite ( $\mathrm{SiC} / \mathrm{SiC})$ from DuPont Lanxide Corporation and B.F. Goodrich Aerospace - Supertemp as well as aluminum oxide $\left(\mathrm{Al}_{2} \mathrm{O}_{3} / \mathrm{Al}_{2} \mathrm{O}_{3}\right)$ liners from Babcock \& Wilcox. These materials are relatively expensive; a typical 8 inch subscale liner costs about $\$ 30 \mathrm{~K}$. Under Task 8.8 , a major requirement for material selection was substantially lower cost than the CSGT structural composites. The three materials selected for evaluation in subtask 8.8 were as follows:

- $\quad$ B-30 BZP (Barium Zirconia Phosphate) supplied by LoTEC. This material features a near zero coefficient of thermal expansion, eliminating most thermal stresses, and the potential to reduce the $\$ 30,000$ per liner cost of $\mathrm{SiC} / \mathrm{SiC}$ by $94 \%$.

- $\quad \mathrm{CMC} \mathrm{SAIC-8} \mathrm{(Nextel} 440 / \mathrm{Al}_{2} \mathrm{O}_{3}-\mathrm{SiO}_{2}$ ) offers the toughness and strength of a CFCC material at a cost $60 \%$ lower than that of $\mathrm{SiC} / \mathrm{SiC}$. This material is supplied by SAIC.

- Altra KVS $16\left(\mathrm{Al}_{2} \mathrm{O}_{3}\right.$ fibers $\left./ \mathrm{Al}_{2} \mathrm{O}_{3}-\mathrm{SiO}_{2}\right)$ from International Thermoproducts with temperature capability to $3000^{\circ} \mathrm{F}\left(1649^{\circ} \mathrm{C}\right)$ at a cost $90 \%$ lower than that of $\mathrm{SiC} / \mathrm{SiC}$.

\subsection{LOTEC BZP}

The Barium Zirconia Phosphate (BZP) material properties are listed in Table 2. The thermal expansion coefficient can be changed by varying the barium, phosphorous, silicon ratio in the material, as shown in Figure 1.

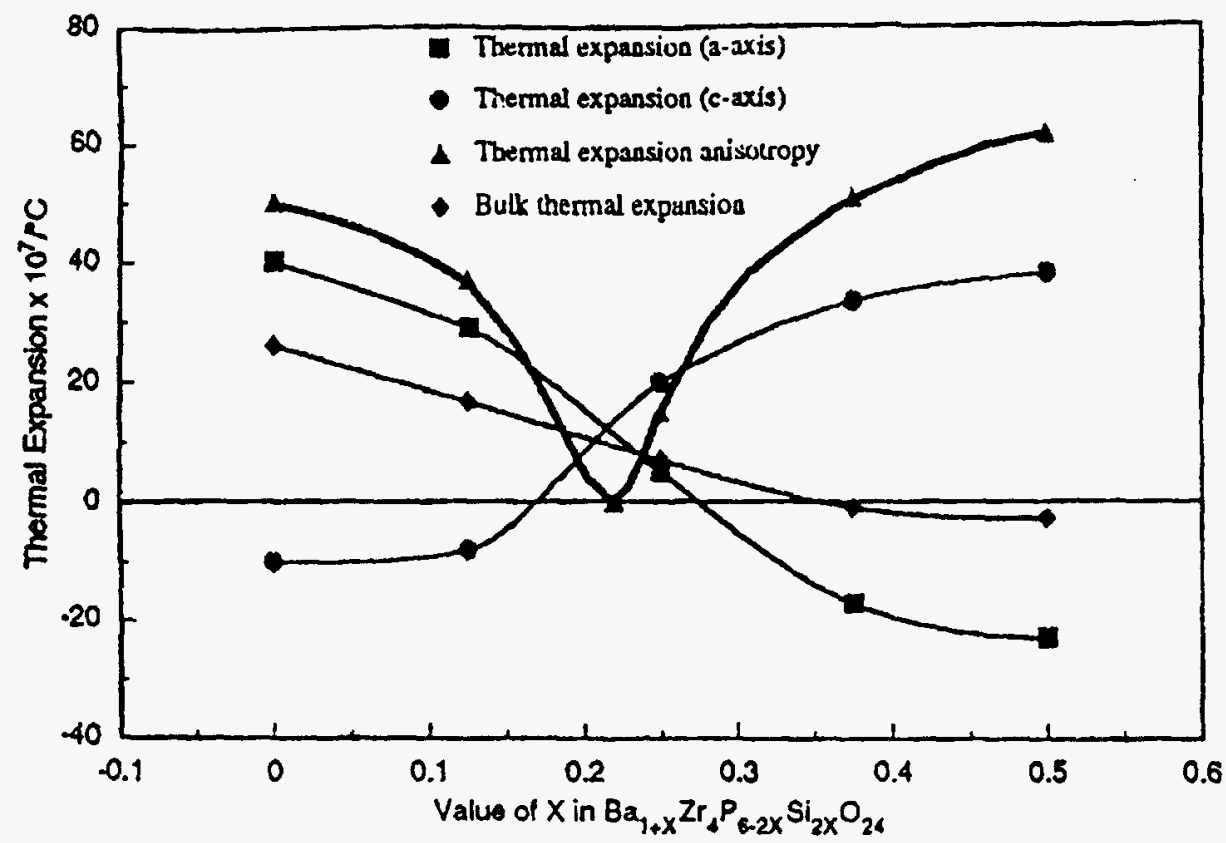

Figure 1. Coefficient of Thermal Expansion Variation with BZP Composition 
Table 2. BZP Material Properties

\begin{tabular}{|c|c|}
\hline Property & \\
\hline Flexural Strength (MOR) & $10 \mathrm{ksi}(70 \mathrm{MPa})$ \\
\hline Flexural Strength at $2732^{\circ} \mathrm{F}\left(1500^{\circ} \mathrm{C}\right)$ & $9 \mathrm{ksi}(65 \mathrm{MPa})$ \\
\hline Young's Modulus & $10 \mathrm{Msi}(70 \mathrm{GPa})$ \\
\hline Poissons Ratio & 0.2 \\
\hline Fracture Toughness & 1.5 to $2 \mathrm{Mpam}{ }^{1 / 2}\left(1.4\right.$ to $1.8 \mathrm{ksi}$ in $\left.{ }^{1 / 2}\right)$ \\
\hline Density & $211 \mathrm{lb} / \mathrm{ft}^{3}\left(3.39 \mathrm{~g} / \mathrm{cm}^{3}\right)$ \\
\hline Thermal Expansion & $1 \mathrm{ppm} /{ }^{\circ} \mathrm{C}\left(1.7 \mathrm{ppm} /{ }^{\circ} \mathrm{F}\right)$ or lower \\
\hline Thermal Expansion Anisotropy & $\leq 1 \mathrm{ppm} /{ }^{\circ} \mathrm{C}\left(1.7 \mathrm{ppm} /{ }^{\circ} \mathrm{F}\right)$ or lower \\
\hline Thermal Conductivity & $1 \mathrm{~W} / \mathrm{mK}\left(7 \mathrm{Btu} . \mathrm{in}^{\mathrm{f}} / \mathrm{ft}^{2} \mathrm{hr}{ }^{\circ} \mathrm{F}\right)$ \\
\hline Thermal Shock Resistance & $\Delta \mathrm{T} \times 2300^{\circ} \mathrm{F}\left(1250^{\circ} \mathrm{C}\right)$ \\
\hline Use Temperature & $U \mathrm{Up}$ to $2732^{\circ} \mathrm{F}\left(1500^{\circ} \mathrm{C}\right)$ \\
\hline
\end{tabular}

The impact of coefficient of thermal expansion on thermal stress was illustrated by a one dimensional stress analysis for the subscale combustor liner running at a $2200^{\circ} \mathrm{F}\left(1204^{\circ} \mathrm{C}\right)$ wall temperature. Results of that analysis, which was done under Solar APDM funding, are in Tables 3 and 4. Increasing the cte from $0.5 \times 10^{-6} /{ }^{\circ} \mathrm{F}$ to $1.7 \times 10^{-6} /{ }^{\circ} \mathrm{F}$ caused a corresponding increase in the stress values. Assuming that the modulus and temperature conditions are constant, the stresses in Table 4 , based on the maximum cte value for BZP $\left(1.7 \times 10^{-6} /{ }^{\circ} \mathrm{F}\right)$, are the maximum stresses for the application. Therefore, the strength of the material was assumed to be adequate.

Table 3. Stresses for BZP Liner with cte $=0.5 \times 10^{-6} /{ }^{\circ} \mathrm{F}$

\begin{tabular}{|c|c|c|}
\hline Stress Direction & Maximum Stress psi (MPa) & Minimum Stress psi (MPa) \\
\hline \hline S1 $[r]$ & $869(5.99)$ & $-48(-.33)$ \\
\hline S2 $(\theta)$ & $290(1.99)$ & $-212(-1.46)$ \\
\hline S3 $(z)$ & $67(0.46)$ & $-855(-5.89)$ \\
\hline SEQV & $892(6.15)$ & $57(.39)$ \\
\hline
\end{tabular}


Table 4. Stresses for BZP Liner with $\mathrm{cte}=1.7 \times 10^{-6} /^{\circ} \mathrm{F}$

\begin{tabular}{|c|c|c|}
\hline Stress Direction & Maximum Stress psi (MPa) & Minimum Stress psi (MPa) \\
\hline \hline S1 [r] & $2956(20.4)$ & $-162(-1.12)$ \\
\hline S2 $(\theta)$ & $986(6.79)$ & $-720(-4.96)$ \\
\hline S3 $(z)$ & $227(1.56)$ & $-2907(-20.0)$ \\
\hline SEQV & $3033(20.9)$ & $194(-1.34)$ \\
\hline
\end{tabular}

\subsection{SAIC CMC-8}

SAIC supplied the only continuous fiber reinforced ceramic composite (CFCC) that was investigated under this program. The material is manufactured using a pre-ceramic polymer impregnated fabric which can be processed using polymer based composite autoclave techniques. The combustor part was laid up by hand on a mandrel and autoclaved on a female tool. Using this method to process the part allowed SAIC to price their liner $60 \%$ less than other CFCC materials. The material system used was Nextel 440 fabric with a proprietary silica based matrix. Since this material was in its infancy, mechanical property data was not available. Therefore, mechanical data (Table 5) generated on a similar composite reinforced with S2 glass was used for evaluation. The strength and modulus values were expected to be greater for the liner than for the data given, since the part fiber volume was about $60 \%$ instead of $50 \%$. Based on a tensile strength of $20.9 \mathrm{ksi}(144 \mathrm{MPa})$, the material was assumed to have adequate strength for the combustor application. Also, the relatively low modulus was expected to reduce thermal stresses developed in the part at temperature. The matrix was expected to devitrify around 1800 to $2200^{\circ} \mathrm{F}\left(982\right.$ to $\left.1204^{\circ} \mathrm{C}\right)$. The effects of devitrification were not known, but the material was expected to return to its original state after going through devitrification.

The main advantages of this system include low cost for good thermal performance, good thermal shock resistance, and an expected graceful CFCC failure mode. Thermal shock resistance for this material was demonstrated in a rocket launch pad application at $3200^{\circ} \mathrm{F}\left(1760^{\circ} \mathrm{C}\right)$ for 1 hour. This material was also tested as a fire door for 4 hours at $2500^{\circ} \mathrm{F}\left(1371^{\circ} \mathrm{C}\right)$.

Table 5. Material Properties of SAIC S2 Glass Reinforced CMC-8

\begin{tabular}{|c|c|c|}
\hline Property & Room Temperature & $550^{\circ} \mathrm{F}\left(\mathbf{2 8 8 ^ { \circ } \mathrm { C } )}\right.$ \\
\hline \hline Tensile Strength, ksi (MPa) & $20.9(144)$ & na \\
\hline Tensile Modulus, Msi (GPa) & $3.2(22)$ & na \\
\hline Tensile Strain, $\mu \mathrm{in} / \mathrm{in}(\mu \mathrm{m} / \mathrm{m})$ & 6614 & na \\
\hline Short Beam Shear, ksi (MPa) & $1.6(11)$ & $0.790(5.44)$ \\
\hline Flexural Strength, ksi (MPa) & $26.5(183)$ & $15.1(104)$ \\
\hline Flexural Modulus, Msi (GPa) & $3.0(21)$ & $2.7(19)$ \\
\hline
\end{tabular}




\subsection{INTERNATIONAL THERMOPRODUCTS ALTRA KVS 16 WITH CERAMIC FABRIC REINFORCEMENT}

The liner from International Thermoproducts was fabricated using a vacuum forming and firing technique which bonds micron size fibers into a fibrous ceramic structure. CF3000, a blend of ultra pure bulk aluminosilicate ceramic fibers and inorganic binders, was used for the Task 8.8 part. This refractory based material, rated to $3000^{\circ} \mathrm{F}\left(1649^{\circ} \mathrm{C}\right)$, is used primarily for high temperature industrial fumace applications and is not a structural ceramic. Advantages of using this low density material include high thermal shock resistance and low thermal conductivity. Also, unlike dense ceramics, spalling of the CF3000 does not pose a threat to downstream components. In the combustor application, it is intended to act as a thermal barrier and not as a structural, mechanical stress carrying member. Therefore, mechanical property data was not generated under this task. Physical property data is listed in Table 6.

This material is much softer than the other materials, but a proprietary method was used to increase its erosion resistance for the combustor application. To qualify it in terms of erosion and thermal shock resistance, thermal cycle testing was performed by ITP. The sample configuration for these tests is half of an eight inch diameter liner. Heat is applied to the inner wall of the cylinder. Initially, two fibers blends, one rated at $2300^{\circ} \mathrm{F}\left(1260^{\circ} \mathrm{C}\right)$ and one rated at $3000^{\circ} \mathrm{F}\left(1649^{\circ} \mathrm{C}\right)$ were tested. Both were cycled about every two minutes for 695 cycles per day. Natural gas was used to heat the samples to between $2200^{\circ} \mathrm{F}\left(1204^{\circ} \mathrm{C}\right)$ and $2400^{\circ} \mathrm{F}\left(1316^{\circ} \mathrm{C}\right)$. Cold cycle temperatures were estimated to be between $600^{\circ} \mathrm{F}\left(316^{\circ} \mathrm{C}\right)$ and $800^{\circ} \mathrm{F}\left(427^{\circ} \mathrm{C}\right)$. Both samples survived 17,000 cycles and showed no evidence of surface cracking or wear. The implication from these results is that the lower cost $2300^{\circ} \mathrm{F}$ rated material may be sufficient for the combustor application.

Currently, ITP is testing samples of the fiber blend rated at $2300^{\circ} \mathrm{F}\left(1260^{\circ} \mathrm{C}\right)$, one without ceramic fabric reinforcement and one with ceramic fabric reinforcement. The sample with fiber only has survived over 75,000 cycles. The sample with fabric reinforcement has survived over 53,000 cycles. Neither shows signs of cracking or erosion.

Table 6. Physical Properties of CF3000 Vacuum Formed Ceramic Fiber

\begin{tabular}{|c|c|}
\hline Property & \\
\hline Color & White \\
\hline Continuous Use Temperature & $3000^{\circ} \mathrm{F}\left(1649^{\circ} \mathrm{C}\right)$ \\
\hline Melting Point & $3392^{\circ} \mathrm{F}\left(1867^{\circ} \mathrm{C}\right)$ \\
\hline Nominal Density & $20 \mathrm{lb} / \mathrm{ft}^{3}\left(.32 \mathrm{~g} / \mathrm{cm}^{3}\right)$ \\
\hline Mean Fiber Diameter & $2-3 \mu \mathrm{m}(79 \mu \mathrm{in})$ \\
\hline Fiber Lengths & $0.25 \mathrm{in}$ to $4 \mathrm{in}(6.4 \mathrm{~mm} \mathrm{to} 102 \mathrm{~mm})$ \\
\hline Chemical Composition & $80 \% \mathrm{Al}_{2} \mathrm{O}_{3}, 20 \% \mathrm{SiO}_{2}$ \\
\hline
\end{tabular}




\subsection{SUBSCALE RIG TESTING}

The liners were tested in Solar's high pressure single can subscale rig using a SoLoNOx fuel injector. This facility has the capability to achieve engine rated pressure and temperature while maintaining a single injector's mass flow into the rig. It is fully instrumented for temperature, pressure, flow, and emissions measurement. A fuel shut-off system is activated at the beginning of each test. It is triggered whenever the wall temperature at any measured location exceeds a predetermined maximum. All data are captured via a Daytronics data acquisition system and VAX workstation which uses a Real Time Engine Test System (RETS) software package. Exhaust emissions are taken with a state of the art Rosemount Analytical continuous emission monitoring system (CEMS). Natural gas was used for fuel in all of the tests.

Each liner was instrumented with fifteen thermocouples attached to the outside with an alumina based adhesive. The thermocouples were arranged in three axial rows of five. Axial and circumferential spacing were about 1.25 inches and $120^{\circ}$, respectively. Nextel 440 is used to insulate the liner and as a compliant layer between the ceramic liner and the metallic housing of the rig. The metallic housing is shown in Figure 2. The insulation layer is typically 0.125 inch thick.

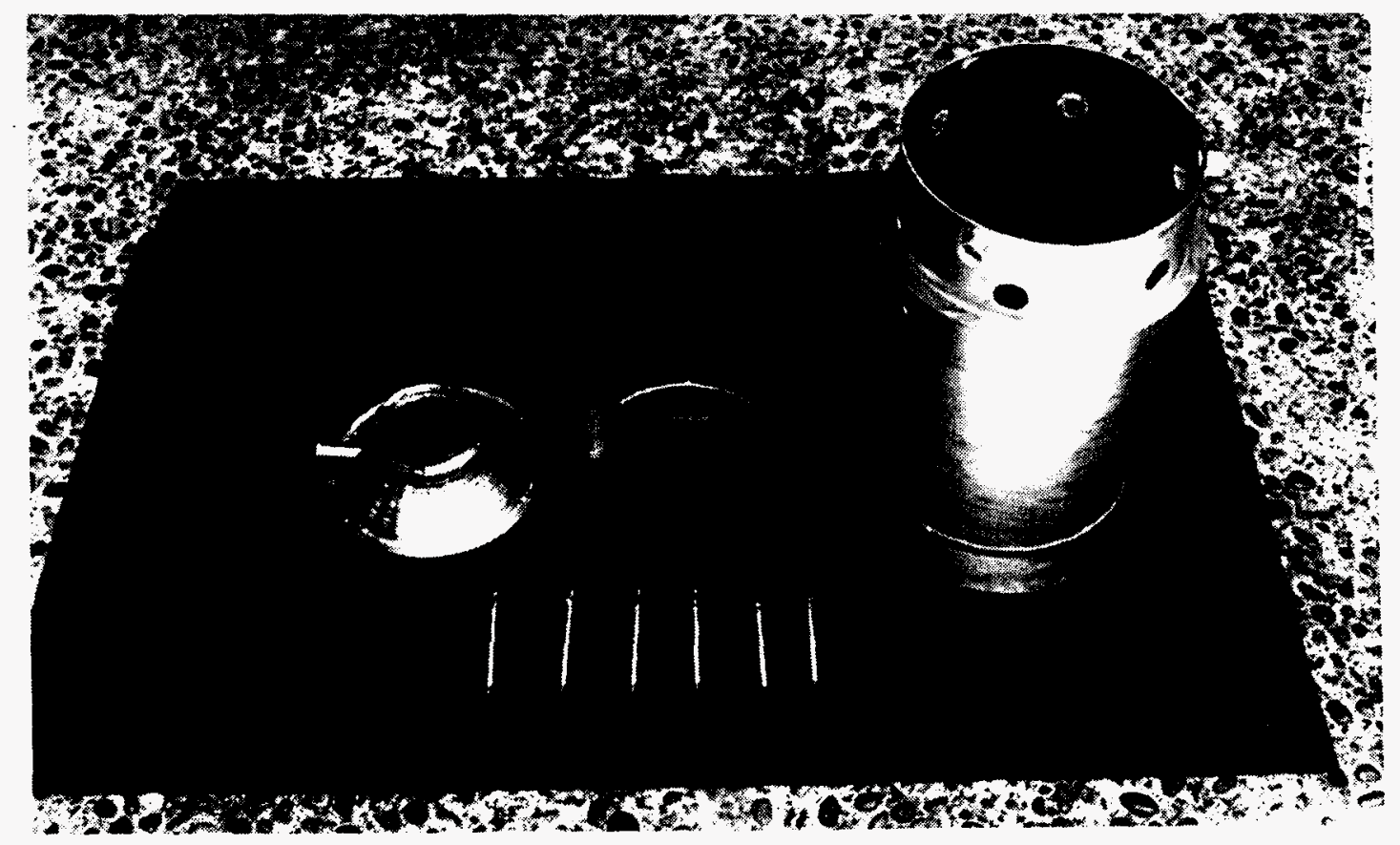

Figure 2. Metallic Housing for Combustor Liner

Each liner was approximately eight inches in outer diameter, and eight inches in length. The thickness of the LOTEC and ITP liners was approximately 0.375 inch. Thickness of the SAIC liner was about 0.125 inch. The LOTEC liner is shown in Figure 3 as an example of the part configuration.

\subsection{LOTEC BZP LINER SUBSCALE RIG TEST}

In the BZP liner test, the rig was lit successfully, and main fuel was introduced slowly to increase wall temperature to the target of $1925^{\circ} \mathrm{F}\left(1052^{\circ} \mathrm{C}\right)$. When the maximum wall temperature was 


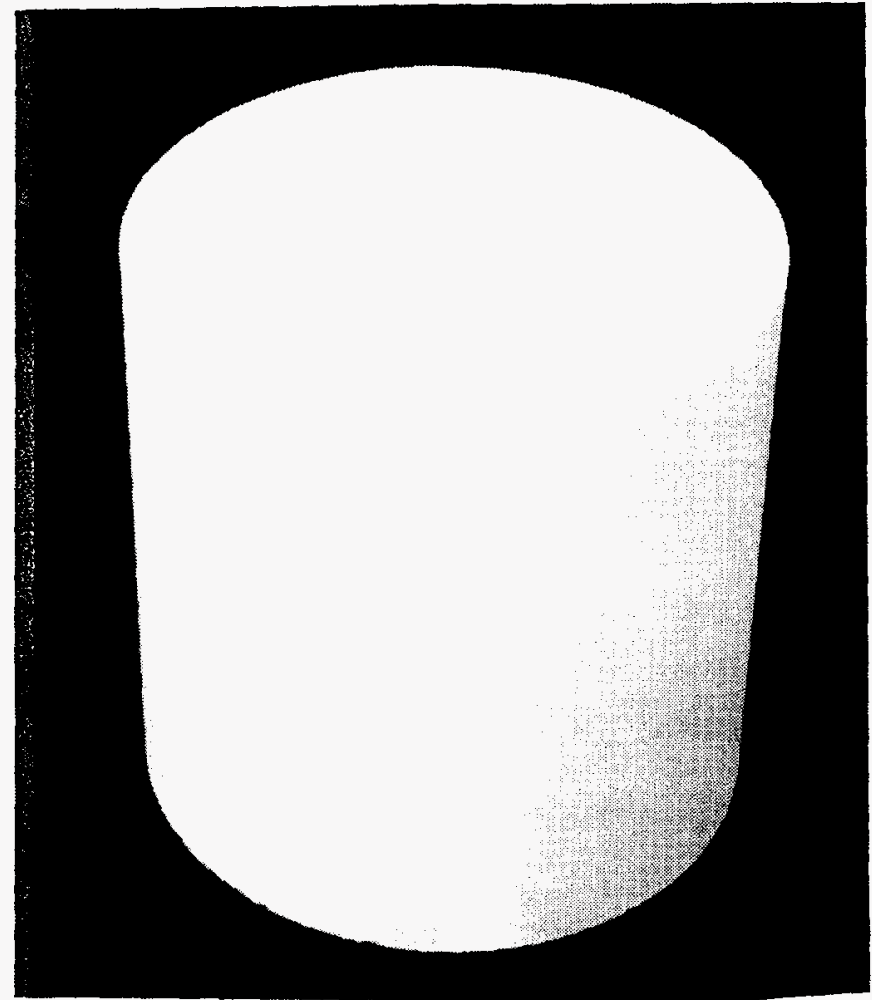

Figure 3.

LOTEC Subscale Combustor Liner Used for Rig Testing

approximately $1500^{\circ} \mathrm{F}\left(816^{\circ} \mathrm{C}\right)$, a change in the sound of the rig was heard. Seconds later, one of the thermocouples overtemped and caused an automatic shutdown of the rig. The thermocouple was exposed to the combustion gases due to catastrophic failure of the liner, eight minutes into the test. Post-test examination of the liner pieces indicated that the liner probably failed from thermal shock. Also, the fracture pattern suggested that failure originated from a large inclusion in the material. Even though the coefficient of thermal expansion is extremely low in this material, some thermal stress is still generated. The strength of this material is very low, and the presence of large inclusions drops the critical failure stress even lower. Therefore, it is assumed that the stresses generated were high enough to cause failure of the liner.

\subsection{SAIC CMC-8 LINER SUBSCALE RIG TEST}

The SAIC liner was lit successfully, and main fuel was introduced slowly to increase the wall temperature to $1925^{\circ} \mathrm{F}\left(1052^{\circ} \mathrm{C}\right)$. While trying to increase the wall temperature, the wall color changed to yellow/orange, and the material sparked. Nine minutes into the test, the wall temperature raced to $1995^{\circ} \mathrm{F}\left(1091^{\circ} \mathrm{C}\right)$ and the rig shut down automatically. The rig was opened and the liner was found in pieces. Post-test evaluation revealed that the composite exhibited extremely brittle failure with no fiber pullout. Figure 4 shows the smoothness of the failure surface in one piece of the failed part. The fracture pattern was indicative of thermal shock. The nature of this failure indicates that SAIC did not obtain adequate fiber/matrix interface properties to provide composite behavior in this part. Also, the material was easily broken apart by hand and did not have mechanical properties similar to those listed in Table 5.

\subsection{ITP CF3000 LINER SUBSCALE RIG TEST}

In addition to the fifteen exterior thermocouples, three thermocouples were embedded through the thickness to the interior wall, spaced about $120^{\circ}$ apart at the mid-plane of the liner. The ITP liner was lit successfully on pilot fuel, and main fuel was added slowly to increase the wall temperature to $2000^{\circ} \mathrm{F}\left(1093^{\circ} \mathrm{C}\right)$. However, only a few minutes into the test, several wall temperatures went over 


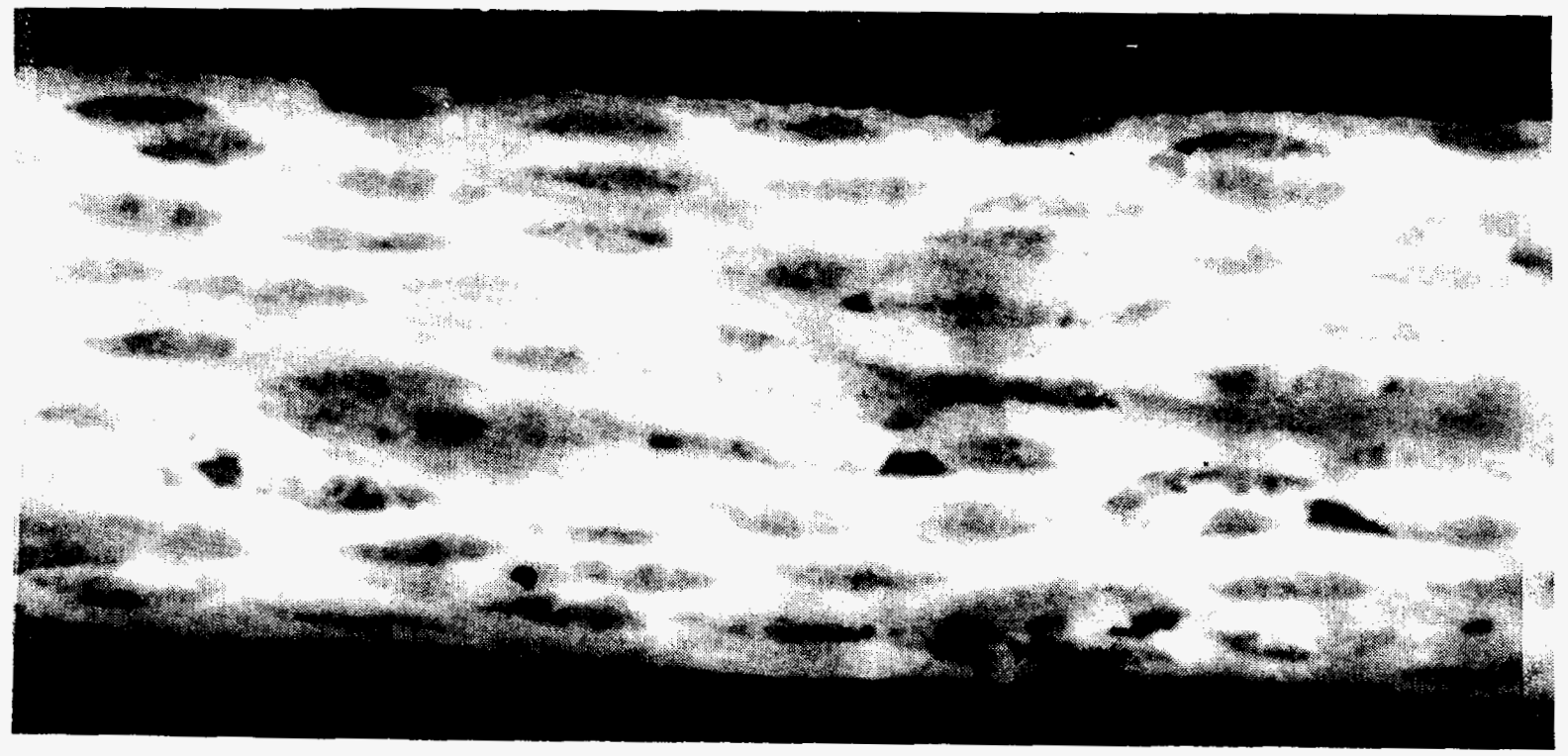

Figure 4. Fracture Surface of Small Fragment SAIC CMC-8

$2000^{\circ} \mathrm{F}\left(1093^{\circ} \mathrm{C}\right)$. The liner was found in the rig in large and small pieces. The nature of the failure is not entirely clear. Since this material is a refractory and is not dense, thermal shock is not a likely cause of failure. One possible cause of failure includes mechanical stress induced by a slight difference in pressure between the outside diameter and the inside of the liner. This material is very fibrous, has little mechanical strength and can be crushed by very low levels of stress. Another possible cause is stress induced by vibration. 


\subsection{CONCLUSIONS AND RECOMMENDATIONS}

The LOTEC BZP and SAIC CMC-8 liners failed due to a lack adequate strength and thermal shock resistance. Although these materials are very low cost, it is not feasible to continue investigation of their use in combustor liner applications.

The ITP CF3000 liner does not have adequate strength to be used in the integral combustor liner configuration. However, because of its thermal insulating capability, thermal shock resistance, and thermal cycling durability, the ITP material warrants further investigation. Solar will work with ITP engineers to develop new concepts that will take advantage of the material's thermal properties while protecting it from mechanically induced failures. Three concepts that have been identified for study include the following:

- A CF3000 with ceramic fabric liner press fit into a high temperature metallic liner backing for strength.

- A CF3000 with ceramic fabric liner in a concentric ring configuration for stress relief.

- An CF3000 with ceramic fabric liner in a half cylinder configuration for stress relief.

ITP will produce drawings of these concepts for Solar's review. Solar will then decide whether to pursue any or all of the concepts using internal funding. 


\section{M98002020}

||||||||||||||||||||||||||||||||||||||||||||||||||||||||||

Report Number (14) DOE/MC/30246- $58 / 2$

subl. Date (11) 1997

sponsor code (18) DOE/FE, XF

$J C$ Category (19) $4 C-101$, DOE/ER 